\title{
Derivation of RCM-driven potential evapotranspiration for hydrological climate change impact analysis in Great Britain: a comparison of methods and associated uncertainty in future projections
}

\author{
C. Prudhomme ${ }^{1, *}$ and J. Williamson ${ }^{1}$ \\ ${ }^{1}$ Centre for Ecology and Hydrology, Wallingford, UK \\ *now at: Dwr Cymru, Welsh Water, Caernarfon, UK \\ Correspondence to: C. Prudhomme (chrp@ceh.ac.uk)
}

Received: 4 December 2012 - Published in Hydrol. Earth Syst. Sci. Discuss.: 15 January 2013

Revised: 13 March 2013 - Accepted: 20 March 2013 - Published: 10 April 2013

\begin{abstract}
Potential evapotranspiration (PET) is the water that would be lost by plants through evaporation and transpiration if water was not limited in the soil, and it is commonly used in conceptual hydrological modelling in the calculation of runoff production and hence river discharge. Future changes of PET are likely to be as important as changes in precipitation patterns in determining changes in river flows. However PET is not calculated routinely by climate models so it must be derived independently when the impact of climate change on river flow is to be assessed. This paper compares PET estimates from 12 equations of different complexity, driven by the Hadley Centre's HadRM3-Q0 model outputs representative of 1961-1990, with MORECS PET, a product used as reference PET in Great Britain. The results show that the FAO56 version of the PenmanMonteith equations reproduces best the spatial and seasonal variability of MORECS PET across GB when driven by HadRM3-Q0 estimates of relative humidity, total cloud, wind speed and linearly bias-corrected mean surface temperature. This suggests that potential biases in HadRM3-Q0 climate do not result in significant biases when the physically based FAO56 equations are used. Percentage changes in PET between the 1961-1990 and 2041-2070 time slices were also calculated for each of the 12 PET equations from HadRM3-Q0. Results show a large variation in the magnitude (and sometimes direction) of changes estimated from different PET equations, with Turc, Jensen-Haise and calibrated Blaney-Criddle methods systematically projecting the largest increases across GB for all months and Priestley-
\end{abstract}

Taylor, Makkink, and Thornthwaite showing the smallest changes. We recommend the use of the FAO56 equation as, when driven by HadRM3-Q0 climate data, this best reproduces the reference MORECS PET across Great Britain for the reference period of 1961-1990. Further, the future changes of PET estimated by FAO56 are within the range of uncertainty defined by the ensemble of 12 PET equations. The changes show a clear northwest-southeast gradient of PET increase with largest (smallest) changes in the northwest in January (July and October) respectively. However, the range in magnitude of PET changes due to the choice of PET method shown in this study for Great Britain suggests that PET uncertainty is a challenge facing the assessment of climate change impact on hydrology mostly ignored up to now.

\section{Introduction and background}

Evaporation occurs when water is converted from a liquid state into a vapour state. The rate of evaporation is controlled by the availability of energy at the evaporating surface and the ease with which water vapour can diffuse into the atmosphere (Allen et al., 1998; Shuttleworth, 1993). Evapotranspiration is the sum of water lost through evaporation from open water, soil and plant surfaces and the water emitted by plants during the process of transpiration. Evapotranspiration is limited by soil water availability, radiation (in terms of energy and photosynthetically active radiation) and the 
humidity of the surrounding air. Soil water availability depends on antecedent precipitation and evaporation, the depth and type of soil and the rooting depth of the overlying vegetation. When soil moisture is not a limiting factor, evapotranspiration can take place at the maximum possible rate determined by the environmental conditions; this is termed potential evapotranspiration (PET). In most environments soil moisture has a limiting effect on transpiration, causing plant stress and the onset of water-saving mechanisms such as stomatal closure, and the real loss of water to the atmosphere is termed actual evapotranspiration (AE). Plants can only transpire the water available to them so $\mathrm{AE}$ can vary from 0 (no water available) to a maximum equal to the PET.

Accurate estimates of the PET variability throughout the year and in different locations are critically important for use in conceptual hydrological modelling. This is because such models calculate the water balance, and PET provides an upper limit to losses by evaporation. Depending on the amount of water available in the stores accessible by vegetation, calculated actual evaporation can vary between 0 (if the soil is dry) and PET. The water remaining after the evaporation processes are satisfied is then available for runoff. The magnitude of PET is critical for regions and seasons where gains through precipitation are of similar magnitude to PET as a slight difference in PET magnitude might result in soil water being a limiting factor (or not) to evaporation. An overestimation of PET could result in runoff and subsequent river discharge being underestimated as too much water would be lost to evaporation; conversely PET underestimation would generate too much runoff and overestimate river discharge.

In the UK, the UK Meteorological Office Rainfall and Evaporation Calculation System (MORECS) provides monthly PET estimates based on the Penman-Monteith equations but considering different soil types (Hough and Jones, 1997); the version used here is based on short grass. It has been used as an input to conceptual hydrological models (lumped or semi-distributed) that were calibrated over British catchments and has been shown to lead to accurate hydrological modelling results across most of Great Britain, GB (e.g. Kay et al., 2007). Such models have been used to underpin water resources (e.g. CERF (Young, 2006)) and flood risk management planning under climate change (e.g. PDM (Kay et al., 2007) and CLASSIC (Crooks and Naden, 2007)), hence water policy and regulation in the UK. Because MORECS-PET has been found to result in adequate calibration of conceptual hydrological models (lumped or distributed), we aim to find a method that can reproduce the spatial and seasonal variability described by MORECSPET when using climate data from global or regional climate models (RCMs) so that the impact of climate change on river flow can be assessed.

By definition PET is a theoretical concept that is difficult to measure, so equations deriving PET from measurable climate variables have been developed over several decades by hydrologists and agronomists to assess water availability and irrigation needs. The driving force behind the passage of water molecules from the plant/soil/water surface to the atmosphere is the difference in water vapour pressure between the two (Allen et al., 1998), and as evaporation occurs the surrounding air will gradually become saturated with water until evaporation ceases (Allen et al., 1998). In reality the air at the interface is replaced by drier air at a rate dependent on wind speed. This means that the primary climatological parameters to consider when estimating PET are radiation, wind speed, humidity and air temperature (Allen et al., 1998), with wind speed showing more control of PET at hourly time scales and temperature and relative humidity showing more importance at longer time scales (Xu and Singh, 1998).

Methods of estimating PET can be physically based and use all climate variables linked to evaporation processes. Penman (1948) was the first to derive an equation which combines the energy required to sustain evaporation and an empirical description of the diffusion mechanism by which energy is removed from the surface as water vapour (Shuttleworth, 1993). This has become known as a combination equation. Different versions of the combined equation can be found in the literature (Monteith, 1965; Penman, 1948) including the FAO56 equation which includes aerodynamic and surface resistance (Allen et al., 1998). As relative humidity and temperature have been found to be the most important variables for estimating PET, empirical methods have been devised using fewer variables. These have the potential advantage that PET estimates can be made for regions where the full suite of climatological data is not available. In this study the empirical equations have been split into two broad categories: those based on net radiation and those based on temperature (Appendix A). The ability of empirical PET equations to produce accurate estimates of PET is still debated. Oudin et al. (2005) found that their temperaturebased equation gave results that were well suited as input for rainfall-runoff models, while Donohue et al. (2010) found that the Penman-Monteith equation captured changes in evaporative demand most accurately. When considering the partitioning of heat fluxes implicit in the combined equations and the more complex radiation-based equation such as Priestley-Taylor, Chin (2011) showed that method performance was dependent on ecosystem type with the PriestleyTaylor equation outperforming the Penman-Monteith equation over open water, while the Penman-Monteith equation was preferable for marsh- and grassland.

For projections of future river flows to be made at a national scale, time series of future PET must be available so that hydrological models can simulate river flow under future climate conditions. Changes in PET are likely to be particularly critical for regions where losses by evaporation are currently of similar magnitude to precipitation during the transition months of spring and autumn, as that is when evaporation might become limited by moisture availability - for example due to an increase in PET due to temperature rise, 
a decrease in precipitation totals or both. However, climate models do not provide estimates of PET but only estimate actual evaporative losses. This means that PET estimates (or changes) need to be generated independently but consistently with future climate projected by climate models so that they can be used in hydrological models. One example for GB is Bell et al. (2011) who used RCM outputs to generate PET time series. Because of the biases associated with climate models projections (see for example Christensen et al., 2010), some scientists have favoured simpler PET equations requiring fewer climate variables than the more physically based methods (Ekström et al., 2007; Kay and Davies, 2008). However their dependency on a few variables, often primarily temperature, might put too much weight on temperature increase and ignore changes in other variables such as radiation and humidity. Finally, while evaporation simulated by global and regional models can be used to estimate PET (e.g. Bell et al., 2011), hydrologists often rely on climate change projections described as mean monthly changes between a reference and a future time slice (change factors, CFs) to generate their climate change scenarios (e.g. Christierson et al., 2012). CFs are typically provided for precipitation, air surface temperature, relative humidity and cloud cover, and sometimes also include net short-wave and long-wave radiation. They rarely consider wind speed, and so far CFs have not been provided for changes in evaporation (actual or potential). An example of CF widely used in the UK is the probabilistic sample of the UKCP09 developed by the UK Climate Impact Programme, which contains 10000 sets of mean monthly CF for GB (Murphy et al., 2009) for temperature (mean monthly, mean daily maximum and minimum, warmest and coolest day, warmest and coolest night), precipitation (mean and on wettest day), mean sea level pressure, total cloud, relative and specific humidity, net surface long and short wave, total downward surface short-wave flux. If river flow simulations driven by transient climate projections (often limited to a few climate model runs) are to be compared with changes including a fuller uncertainty (e.g. UKCP09), both must use the same equations to calculate PET so as to allow direct comparison. We have hence restricted the climate variables used here from HadRM3-Q0 to those also available from the probabilistic sample UKCP09.

This study aims to identify the most suitable PET equation with which to construct time series of PET to use in hydrological modelling of GB, based on HadRM3-Q0 climate simulations. As hydrological models calibrated using MORECS PET are already available for a range of catchments in GB, we seek PET equations that best reproduce the spatial and seasonal variability of MORECS PET across GB. This study compares PET estimates derived from 12 empirical equations driven by outputs from the Hadley Centre's HadRM3Q0 model (unperturbed model variant of the HadRM3-PPE ensemble from UKCP09) for the baseline reference (1961$1990)$ and future (2041-2070, or 2050s) time slices. The methods are evaluated based on their ability to reproduce the spatial and seasonal variability of MORECS PET for the baseline period, while we also discuss the changes estimated between baseline and the 2050s future time horizon. The PET formulations considered are presented in the next section along with the climate data inputs. Section 3 presents the results obtained for Great Britain, followed by a discussion and recommendation on the PET formulation method to use to undertake climate change impact studies on river flow in Great Britain.

\section{Methods}

\subsection{PET methods}

Twelve PET methods are used in this paper: two combined methods (FAO56 and a modified (mod) version of Penman-Monteith), five radiation-based methods (PriestleyTaylor, Turc, Jensen-Haise, Makkink, and Priestley-Taylor Idso-Jackson) and five temperature-based methods (Hamon, McGuinness-Bordne, Oudin, Blaney-Criddle, and Thornthwaite). The associated equations are given in Appendix A in order of decreasing complexity (valid for daily to monthly time step).

The most complex methods (FAO56 and PenmanMonteith mod) combine a representation of the energy required to sustain evaporation with an empirical description of the diffusion mechanism by which energy is removed from the surface as water vapour (Shuttleworth, 1993). FAO56 is a widely used PET method (Allen et al., 1998), recommended for use by the Food and Agricultural Organization based on the Penman-Monteith equations while Penman-Monteith (mod) refers to a modification of the Penman-Monteith equation suggested for use with the HadRM3 model outputs (Kay et al., 2003). Note that here we use the formulation described by Shuttleworth (1993) to estimate net radiation instead of using HadRM3-Q0 estimates directly. This is because UKCP09 CF for long- and short-wave equations cannot be used in combination with CF for precipitation, temperature and humidity as they are derived independently (see Sect. 2.2.2).

As the first term of the combination equations (energy component) frequently exceeds the second (diffusion component) by a factor of about four (see Sect. 1 in the Supplement), Shuttleworth (1993) suggests that it might be possible to derive a simpler empirical relationship between evaporation and radiation. The following radiation-based formulations exploit this approximation. Priestley and Taylor proposed a simplified version of the combination equation where the aerodynamic component was neglected and the energy component multiplied by a co-efficient (Priestley and Taylor, 1972). A simplification of the Priestley-Taylor method (Priestley-Taylor Idso-Jackson) uses air temperature rather than vapour pressure to define net radiation (see Shuttleworth, 1993). In humid climates the Turc equation (Turc, 
Table 1. Monthly Blaney-Criddle parameters fitted for GB to reproduce $40 \mathrm{~km}$ MORECS spatial pattern of long-term mean monthly PET (186 grid cells were used). The $R^{2}$ statistic gives a measure of the goodness of fit.

\begin{tabular}{lrcc}
\hline & $\alpha$ & $k$ & $R^{2}$ \\
\hline January & -0.0556 & 0.3129 & 0.3895 \\
February & -0.3354 & 0.4571 & 0.6425 \\
March & -0.6516 & 0.6439 & 0.6574 \\
April & -2.2882 & 1.1354 & 0.7963 \\
May & -4.7247 & 1.6087 & 0.7470 \\
June & -6.8267 & 1.7882 & 0.6635 \\
July & -8.0714 & 1.9678 & 0.8124 \\
August & -5.7814 & 1.6632 & 0.8939 \\
September & -1.9942 & 0.9488 & 0.8003 \\
October & -0.4061 & 0.5032 & 0.5224 \\
November & -0.0366 & 0.3489 & 0.3724 \\
December & 0.1123 & 0.2102 & 0.2173 \\
\hline
\end{tabular}

1961) has been shown to perform well; the version used in this work is given in Shuttleworth (1993), with variations for high and low relative humidity. The Jensen-Haise equation was derived from well-watered alfalfa in the western USA (Jensen and Haise, 1963), and the version of the equation used in this study is from Jensen et al. (1990). The Makkink equation was developed empirically and is commonly used in the Netherlands (Jacobs et al., 2009).

The physical basis for estimating evaporation using temperature alone is that both terms of the combination equation (the energy required to sustain evaporation and the energy removed from the surface as water vapour) are generally related to temperature (Shuttleworth, 1993). Four of the five temperature-based formulations have been developed for use in the USA: the Hamon equation formulates a relationship between PET, temperature and daylight hours (Hamon, 1961); the Thornthwaite equation correlating mean monthly air temperature and PET (Thornthwaite, 1948); and the Blaney-Criddle equations also linking daylight hours and temperature and PET (Blaney and Criddle, 1950). Generally, reference PET over short grass is used (this is the case of the FAO56), but PET for other vegetation was also developed. This is the case of the Blaney-Criddle equations which require the use of a model coefficient $k$, which depends on crop type, location and season. For this study a set of model parameters has been fitted to the MORECS mean monthly PET, and this is referred to as the Blaney-Criddle MORECS formulation (Table 1). Note that MORECS can use a range of surface covers from bare soil to forest, but the simulations used here are for short grass. The most recent formulation used in this study is the Oudin equation, which was calibrated based on catchments in France, Australia and the USA (Oudin et al., 2005). Note that McGuinnessBordne and Oudin use extraterrestrial radiation as a proxy for surface radiation.
The methods for calculating PET are described by the equations of varying complexity (Sect. 1 in Supplement) and require different number and type of climate variables as input. Most of them also involve intermediate variables reflecting the different physical processes occurring in the evaporation process. Commonly used equations for estimating these intermediate processes, summarising some of the water properties and other controlling characteristics of the soilplant-atmosphere system, are given in Sect. 2 in Supplement (Shuttleworth, 1993; Allen et al., 1998; Jensen et al., 1990).

\subsection{Data inputs}

\subsubsection{MORECS}

MORECS PET has been widely used among the British hydrological community as reference potential evapotranspiration since its introduction in 1981 (Hough and Jones, 1997). MORECS uses daily weather data to provide weekly and monthly average PET on a $40 \mathrm{~km}$ grid across the UK, calculated from a modification of the Penman-Monteith equation (Hough and Jones, 1997); here monthly mean MORECSPET for short grass is used. MORECS-PET was available for the period 1961-1990, but note that it can include some inconsistencies over time in some areas due to the change in the measurement network.

\subsubsection{Regional climate model data}

The latest products from the UK Climate Impacts Programme (UKCIP) are in the form of probabilistic climate projections and are the results of an innovative modelling approach from the Met Office Hadley Centre climate model HadRM3-PPE (Murphy et al., 2009). The model uses a perturbed physics ensemble to generate climate projections of different realisations of the future and is run at a $25 \mathrm{~km}$ grid resolution. The resulting ensemble aims to include some of the variability that would be introduced if different climate models (global, GCM or regional, RCM) were used. The ensemble of daily time series (available from www.badc. nerc.ac.uk) consists of a set of 11 physically plausible climate simulations, designed to simulate the UK climate from 1950-2099 for the historical and SRES A1B emissions scenario (IPCC, 2000). The 11 HadRCM3 runs are all driven by the same emissions scenario, but one is run with unperturbed physics (HadRM3-Q0) and the other ten are run with different perturbations to the atmospheric parameterisations (Murphy et al., 2009). These 11 climate scenarios do not account for as much spread and range in the external and climate variability as the probabilistic climate scenarios as there are only 11 realisations of possible future climate. In this study only data from the unperturbed HadRCM3-PPE member (HadRM3-Q0 or afgcx) were used. So that future results can be put in the context of a wider climate change uncertainty as described by the probabilistic ensemble of monthly 
Table 2. HadRCM3-Q0 climate variables used to estimate PET for GB. Last column indicates the set of the UKCP09 probabilistic samples where change factors are available.

\begin{tabular}{llllc}
\hline Variable & RCM code name & RCM stash code & Unit & UKCP09 Set \\
\hline Mean daily temperature & tas & M1s3i236 & $\mathrm{K}$ & 1 \\
Relative humidity & hurs_pc & M1s3i245 & $\%$ & 1 \\
Total cloud (cloudiness fraction) & Total_cloud_lw_rad & M1s2i204 & Fraction & 1 \\
Net surface long-wave flux & longwave & M1s2i201 & $\mathrm{W} \mathrm{m}^{-2}$ & 2 \\
Net surface short-wave flux & solar & M1s1i201 & $\mathrm{W} \mathrm{m}^{-2}$ & 2 \\
\hline Wind speed & wss & M1s3i249 & $\mathrm{m} \mathrm{s}^{-1}$ & - \\
\hline
\end{tabular}

CF UKCP09, only variables in common between HadRM3PPE and UKCP09 are considered (Table 2). The methodology used to generate the UKCP09 probabilistic sample involved two separate independent runs (generating set 1 or set 2) for each grid cell. As a result of this independence, it is not possible to combine data from the two sets. Hence radiation is estimated using Shuttleworth (1993) (see Sect. 1 in the Supplement for equations of net radiation "Rn" based on mean daily temperature, relative humidity and cloudiness fraction). Assuming no change in wind speed and using Shuttleworth (1993) for radiation, changes from all 12 considered methods can be calculated by applying UKCP09 CF to observed monthly climatology (based on 1961-1990 period of observation) for all relevant variables to derive "future PET", which can then be compared with "reference PET" calculated from the same observed monthly climatology, hence providing UKCP09 PET change estimates. This has not been implemented in this paper.

The current generation of RCMs cannot always accurately reproduce some important climate variables, an issue well known for precipitation and temperature, so forms of bias correction have often been applied to RCM outputs for use in impact studies (e.g. Hay et al., 2002; Leander and Buishand, 2007; Terink et al., 2010). While this study is not directly concerned with the accuracy of the RCM climate, it is important that possible biases in the RCM data do not impact significantly on the estimation of PET. In this study temperature from HadRM3-Q0 is not used directly, but a bias-corrected version is used which applied an additive function to the RCM data to better reproduce historical mean air temperature records (Lenderink et al., 2007). This procedure effectively downscales temperature time series from the HadRM3-Q0 scale to the observation scale $(5 \mathrm{~km}$ grids; see Perry et al., 2009). Following Piani et al. (2010) only temperature was bias-corrected.

For the baseline (1961-1990) and future (2041-2069) time slices, $30 \mathrm{yr}$ monthly averages were derived for all variables relevant for PET calculation from HadRM3-Q0 time series, and 12 PET monthly estimates calculated for each land cell. Future projections were then compared with baseline calculations and expressed as percentage departure from the baseline for each month and grid cell.

\section{Results}

Mean monthly average MORECS PET and HadRM3-Q0driven PET for the 12 PET equations for the 1961-1990 time slice are compared using maps showing the spatial distribution of PET values across GB and by fitting a linear regression to paired MORECS and HadRM3-Q0-driven PET values (at the $40 \mathrm{~km}$ MORECS grid) as described by $\mathrm{Xu}$ and Singh (2002). Analyses focus on the year and each individual month.

Recent work has questioned the use of temperature-based methods to estimate changes in PET as the exclusion of trends in other climate variables might result in an overestimation of PET changes (Shaw and Riha, 2011). Projections of change in monthly PET values between the control period and the 2050s (2041-2070) are hence also assessed for the 12 PET methods to evaluate the range of uncertainty associated with PET changes (section 3.2) for four months of the year typical of winter (January), spring (April), summer (July) and autumn (October).

\subsection{Baseline reproduction}

The performances of the 12 PET equations are assessed using visual comparison of scatter plots between paired mean monthly MORECS and empirical PET (Fig. 1), two goodness-of-fit measures RMSE and $R^{2}$ (Table 3) and maps of monthly averages (Fig. 2 and Supplement).

Winter PET values are the lowest with observed mean monthly totals varying between 5 and $30 \mathrm{~mm}$. Values derived using FAO56 and modified Penman-Monteith show consistently the closest relationship with MORECS PET across all three winter months (December to February) with good reproduction of the spatial variability (scatter in Fig. 1) and PET estimates close to MORECS PET (paired distribution close to the $1: 1$ line). In general, winter PET is underestimated by radiation- and temperature-based equations, with the largest underestimations given by the two variants of the Priestley-Taylor equations. Hamon and Blaney-Criddle show no systematic underestimation but fail to reproduce the spatial variability of PET. 


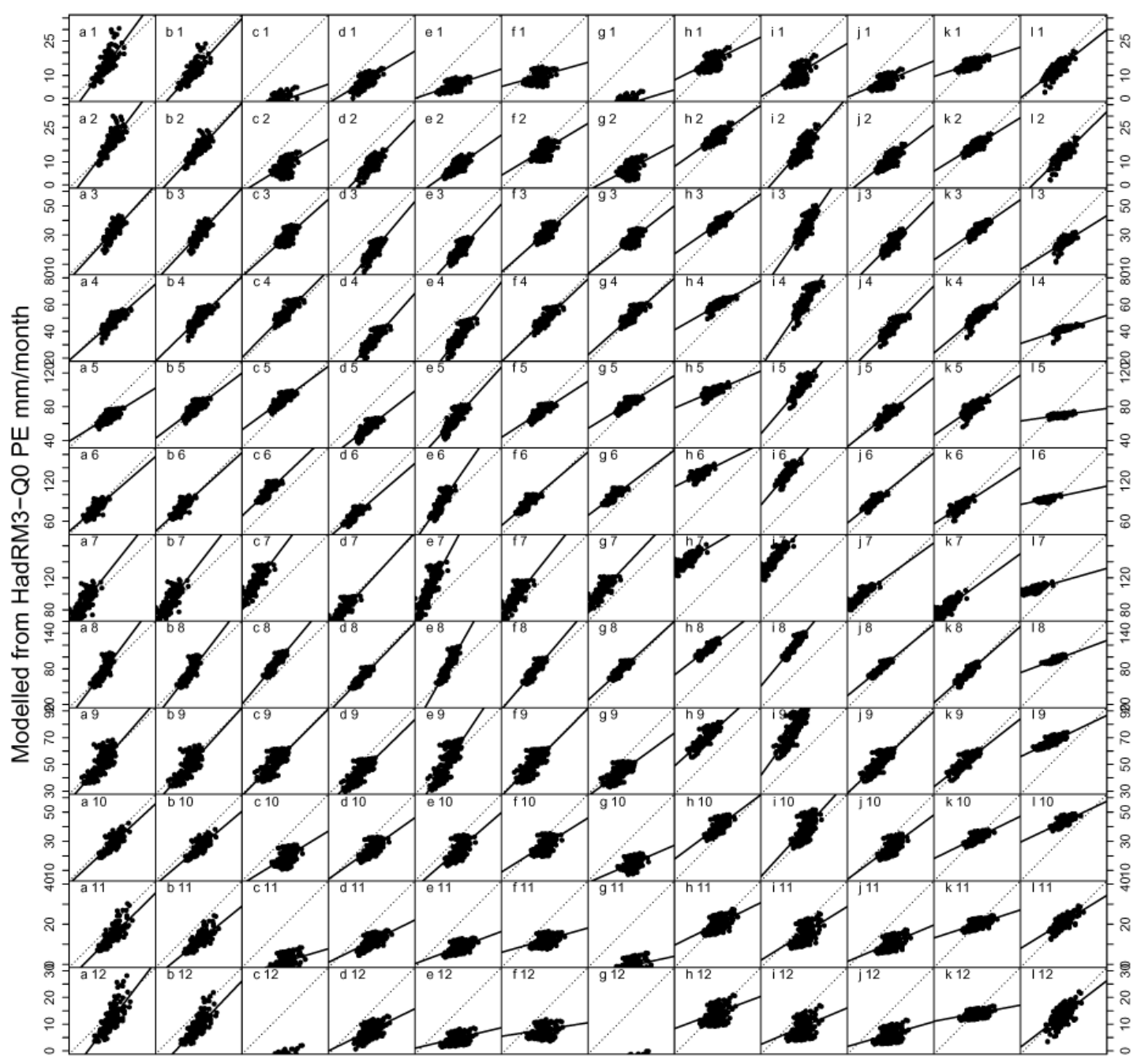

MORECS PE mm/month

Fig. 1. Scatter plots of paired mean monthly MORECS and HadRM3-Q0-driven PET (mm/month) calculated over the 1961-1990 time slice for 12 PET equations (columns) and 12 months (lines). a: FA056; b: Penman-Monteith (mod); c: Priestley-Taylor; d: Turc; e: Jensen-Haise; f: Makkink; g: Priestley-Taylor (Idso-Jackson); h: Hamon; i: McGuinness-Bordne; j: Oudin; k: Blaney-Criddle; 1: Thornthwaite. Month is given as 1 (January)-12 (December). Values are paired by MORECS grid. HadRM3-Q0-driven PET was calculated at the $5 \mathrm{~km}$ grid scale and aggregated to the MORECS grid. The 1: 1 line is the dotted line on each graph. Note variation of scale.

During spring, PET increases as vegetation starts growing under increased radiation and temperature, with mean MORECS PET in GB varying between 20 and $100 \mathrm{~mm}$. While $R^{2}$ values are not necessarily the largest for the combined equations (FAO56 and modified Penman-Monteith), they consistently have small RMSE and show a good reproduction of the spatial variability of MORECS PET for all three months of spring (scatter plot of paired values close to $1: 1$ line, Fig. 1). Turc, Jensen-Haise, and Oudin correctly simulate MORECS PET variability but show a systematic underestimation, while Hamon and McGuinnessBordne show a systematic overestimation across all spring months and in particular for lower PET values. Thornthwaite fails to reproduce any of the spatial variability of MORECS
PET. Makkink and the two variants of Priestley-Taylor show good reproduction of March and April PET but show biases in May.

Summer PET is the largest in Great Britain with mean monthly MORECS PET totals varying between 60 and $120 \mathrm{~mm}$ as vegetation reaches its full growth. Most of the equations overestimate summer PET compared to MORECS PET. The closest reproductions of the spatial variability of MORECS PET are achieved by Turc, FAO56 and modified Penman-Monteith as shown by paired scatter plots, lowest RMSE and acceptable 1:1 correspondence. Priestley-Taylor (both formulations), Jensen-Haise, Hamon, McGuinness-Bordne, Oudin, and Thornthwaite all 

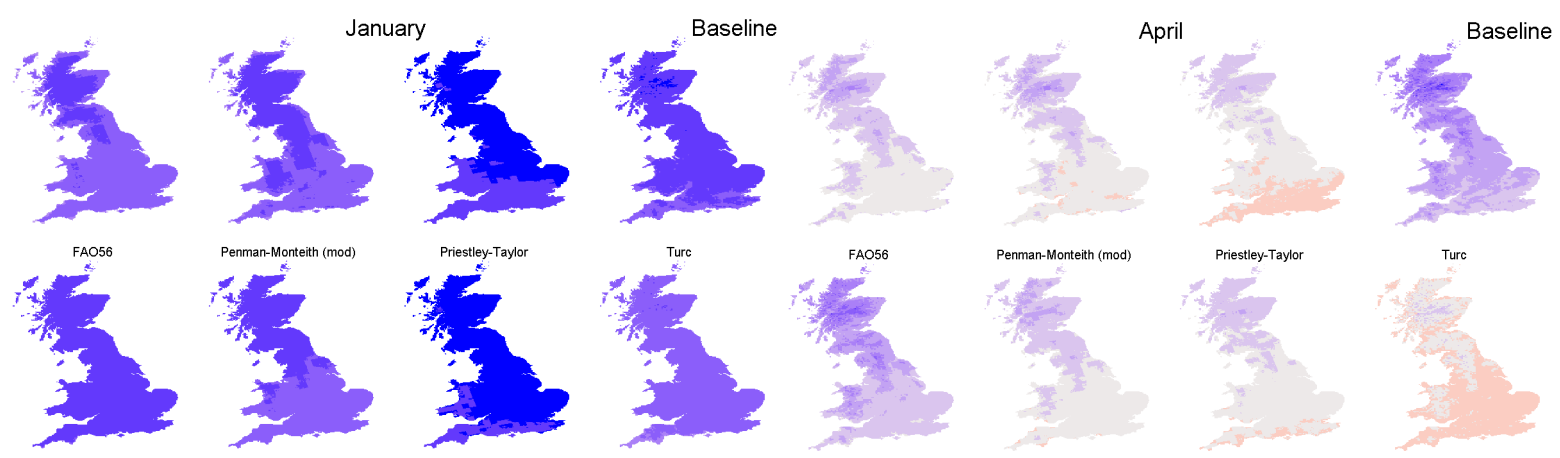

Turc
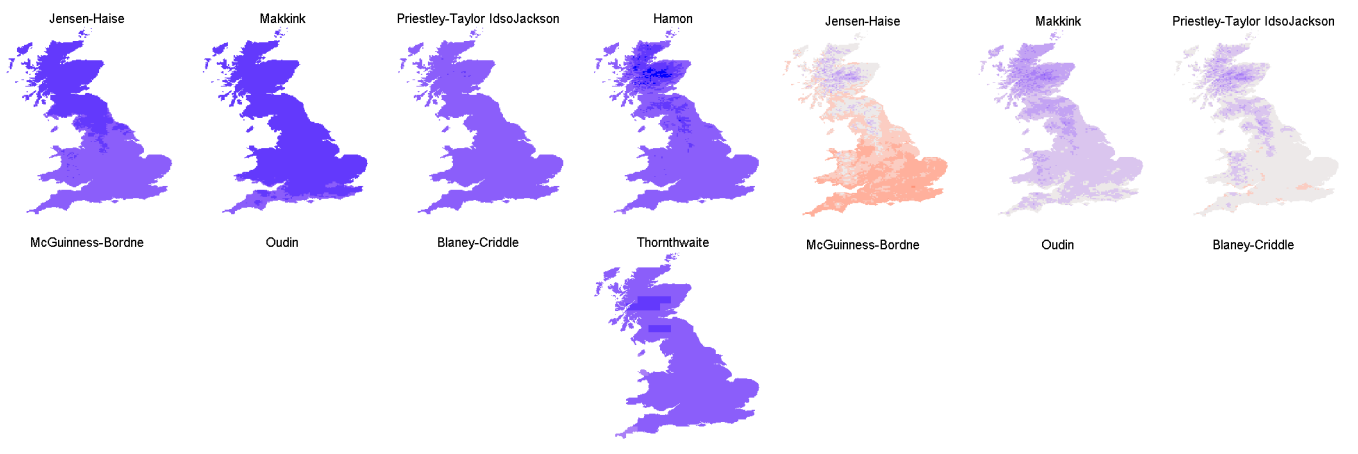

Oudin

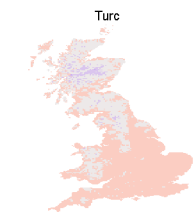

MORECS
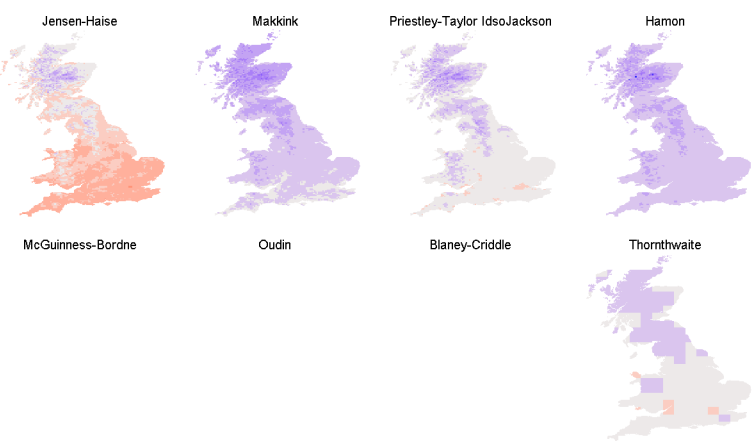

MORECS

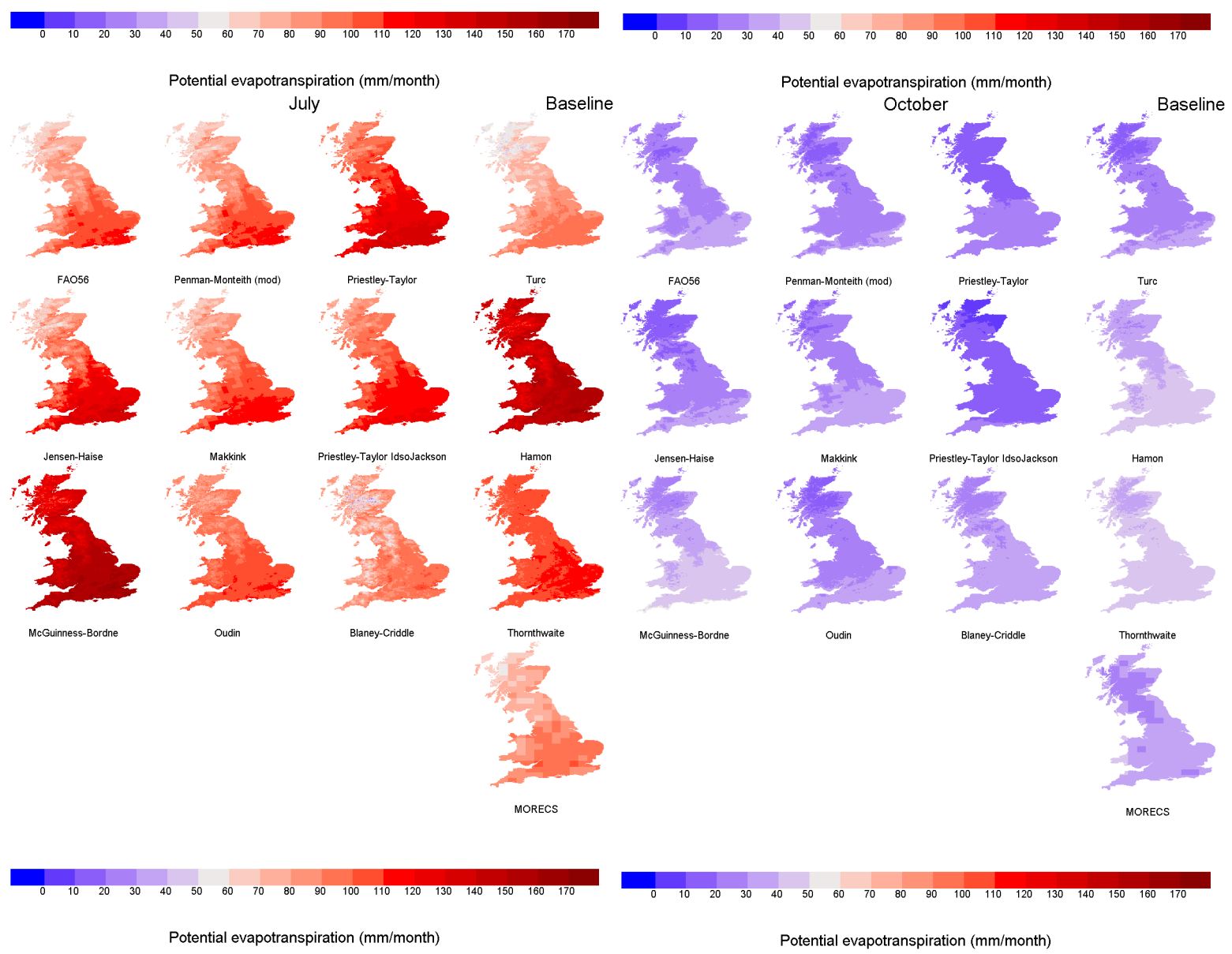

Fig. 2. Maps of average MORECS PET and PET derived from HadRM3-Q0 for the 1961-1990 time slice for four typical months. 
Table 3. Statistical fit between paired mean monthly MORECS and HadRM3-Q0-driven PET calculated over the 1961-1990 time slice for 12 PET equations for the year and four typical months. Values are paired by MORECS grids. HadRM3-Q0-driven PET was calculated at $5 \mathrm{~km}$ grid and aggregated to MORECS grid for comparison. Values in italic highlight the smallest error or closest fit in each case.

\begin{tabular}{|c|c|c|c|c|c|c|c|c|c|c|c|c|c|c|}
\hline \multirow[t]{2}{*}{ Method } & $\begin{array}{c}\text { RMSE } \\
\text { (mm/month) }\end{array}$ & $R^{2}$ & $\begin{array}{c}\text { RMSE } \\
\text { (mm/month) }\end{array}$ & $R^{2}$ & $\begin{array}{c}\text { RMSE } \\
\text { (mm/month) }\end{array}$ & $R^{2}$ & $\begin{array}{c}\text { RMSE } \\
\text { (mm/month) }\end{array}$ & $R^{2}$ & $\begin{array}{c}\text { RMSE } \\
\text { (mm/month) }\end{array}$ & $R^{2}$ & $\begin{array}{c}\text { RMSE } \\
\text { (mm/month) }\end{array}$ & $R^{2}$ & $\begin{array}{c}\text { RMSE } \\
\text { (mm/month) }\end{array}$ & $R^{2}$ \\
\hline & \multicolumn{2}{|l|}{ Year } & \multicolumn{2}{|c|}{ January } & \multicolumn{2}{|c|}{ February } & \multicolumn{2}{|c|}{ March } & \multicolumn{2}{|l|}{ April } & \multicolumn{2}{|l|}{ May } & \multicolumn{2}{|l|}{ June } \\
\hline a. FA056 & 6.41 & 0.95 & 3.14 & 0.57 & 2.81 & 0.62 & 3.12 & 0.56 & 4.41 & 0.71 & 11.68 & 0.59 & 5.50 & 0.63 \\
\hline b. Penman-Monteith (mod) & 6.31 & 0.97 & 4.27 & 0.58 & 2.73 & 0.64 & 3.52 & 0.57 & 2.91 & 0.73 & 4.28 & 0.66 & 5.34 & 0.67 \\
\hline c. Priestley-Taylor & 16.97 & 0.97 & 16.64 & 0.09 & 9.39 & 0.21 & 5.68 & 0.42 & 4.41 & 0.70 & 9.64 & 0.66 & 25.90 & 0.72 \\
\hline d. Turc & 12.00 & 0.94 & 7.41 & 0.39 & 8.61 & 0.59 & 14.54 & 0.62 & 18.00 & 0.75 & 23.38 & 0.70 & 11.32 & 0.74 \\
\hline e. Jensen-Haise & 13.54 & 0.92 & 9.59 & 0.21 & 9.17 & 0.45 & 13.89 & 0.60 & 14.83 & 0.75 & 13.74 & 0.70 & 11.74 & 0.75 \\
\hline f. Makkink & 7.35 & 0.96 & 5.89 & 0.08 & 3.26 & 0.23 & 3.42 & 0.49 & 3.43 & 0.71 & 6.20 & 0.65 & 8.51 & 0.70 \\
\hline g. Priestley-Taylor (Idso-Jackson) & 15.07 & 0.96 & 17.81 & 0.07 & 10.28 & 0.19 & 6.91 & 0.40 & 2.97 & 0.69 & 6.08 & 0.65 & 19.02 & 0.70 \\
\hline h. Hamon & 27.45 & 0.93 & 2.88 & 0.23 & 4.26 & 0.50 & 5.00 & 0.62 & 9.13 & 0.70 & 20.33 & 0.52 & 51.38 & 0.48 \\
\hline i. McGuinness-Bordne & 29.50 & 0.95 & 5.03 & 0.23 & 2.84 & 0.47 & 5.20 & 0.57 & 12.93 & 0.76 & 25.60 & 0.73 & 52.12 & 0.77 \\
\hline j. Oudin & 9.40 & 0.95 & 7.85 & 0.23 & 6.38 & 0.47 & 9.40 & 0.57 & 8.82 & 0.75 & 9.15 & 0.73 & 10.15 & 0.77 \\
\hline k. Blaney-Criddle & 3.69 & 0.98 & 2.15 & 0.29 & 1.50 & 0.57 & 2.04 & 0.62 & 2.68 & 0.71 & 4.60 & 0.60 & 5.79 & 0.55 \\
\hline 1. Thornthwaite & 13.21 & 0.88 & 2.70 & 0.54 & 4.55 & 0.60 & 8.72 & 0.46 & 10.49 & 0.55 & 11.15 & 0.37 & 11.45 & 0.39 \\
\hline \multirow[t]{2}{*}{ Method } & $\begin{array}{c}\text { RMSE } \\
\text { (mm/month) }\end{array}$ & $R^{2}$ & $\begin{array}{c}\text { RMSE } \\
\text { (mm/month) }\end{array}$ & $R^{2}$ & $\begin{array}{c}\text { RMSE } \\
\text { (mm/month) }\end{array}$ & $R^{2}$ & $\begin{array}{c}\text { RMSE } \\
\text { (mm/month) }\end{array}$ & $R^{2}$ & $\begin{array}{c}\text { RMSE } \\
\text { (mm/month) }\end{array}$ & $R^{2}$ & $\begin{array}{c}\text { RMSE } \\
\text { (mm/month) }\end{array}$ & $R^{2}$ & & \\
\hline & \multicolumn{2}{|l|}{ July } & \multicolumn{2}{|c|}{ August } & \multicolumn{2}{|c|}{ September } & \multicolumn{2}{|c|}{ October } & \multicolumn{2}{|c|}{ November } & \multicolumn{2}{|c|}{ December } & & \\
\hline a. FA056 & 9.21 & 0.74 & 8.76 & 0.73 & 5.46 & 0.62 & 5.19 & 0.60 & 6.46 & 0.57 & 4.37 & 0.57 & & \\
\hline b. Penman-Monteith (mod) & 10.32 & 0.76 & 7.72 & 0.75 & 6.43 & 0.62 & 7.64 & 0.58 & 8.89 & 0.57 & 0.26 & 0.56 & & \\
\hline c. Priestley-Taylor & 30.97 & 0.80 & 18.18 & 0.81 & 4.97 & 0.59 & 14.62 & 0.23 & 19.24 & 0.07 & 19.46 & 0.12 & & \\
\hline d. Turc & 7.67 & 0.81 & 7.12 & 0.83 & 8.73 & 0.65 & 8.47 & 0.35 & 9.01 & 0.32 & 7.14 & 0.26 & & \\
\hline e. Jensen-Haise & 24.21 & 0.81 & 17.46 & 0.83 & 6.96 & 0.65 & 9.84 & 0.33 & 12.19 & 0.23 & 9.92 & 0.11 & & \\
\hline f. Makkink & 13.84 & 0.79 & 8.82 & 0.80 & 5.04 & 0.59 & 6.89 & 0.24 & 8.78 & 0.12 & 7.07 & 0.03 & & \\
\hline g. Priestley-Taylor (Idso-Jackson) & 21.15 & 0.79 & 8.88 & 0.79 & 8.86 & 0.54 & 18.88 & 0.18 & 21.23 & 0.04 & 20.88 & 0.01 & & \\
\hline h. Hamon & 60.20 & 0.64 & 42.29 & 0.79 & 18.97 & 0.75 & 7.92 & 0.43 & 3.14 & 0.25 & 3.09 & 0.11 & & \\
\hline i. McGuinness-Bordne & 61.22 & 0.82 & 48.64 & 0.86 & 24.30 & 0.68 & 8.03 & 0.35 & 6.07 & 0.22 & 6.24 & 0.11 & & \\
\hline j. Oudin & 15.62 & 0.82 & 10.48 & 0.86 & 3.84 & 0.68 & 7.74 & 0.35 & 10.14 & 0.22 & 8.61 & 0.11 & & \\
\hline k. Blaney-Criddle & 6.33 & 0.66 & 4.54 & 0.80 & 2.97 & 0.75 & 2.81 & 0.45 & 2.68 & 0.29 & 2.37 & 0.14 & & \\
\hline 1. Thornthwaite & 24.37 & 0.60 & 23.80 & 0.71 & 16.03 & 0.73 & 10.85 & 0.53 & 2.45 & 0.52 & 2.51 & 0.43 & & \\
\hline
\end{tabular}

systematically overestimate July PET in all locations with biases as large as $60 \mathrm{~mm}$ (Hamon and McGuinness-Bordne).

In the autumn the monthly PET values are decreasing (mean monthly MORECS PET between 5 and $70 \mathrm{~mm}$ ) with smallest values in November. Generally MORECS PET is well reproduced in September but underestimated in November with all methods but the combined equations failing to reproduce the spatial variability. Note that Hamon, McGuinness, and Thornthwaite also overestimate PET compared to MORECS in September. Overall, FAO56 shows the closest relationship with MORECS PET: second smallest RMSE in October, highest $R^{2}$ in November, closest to $1: 1$ relationship for all three months.

Over the whole year, Blaney-Criddle provides the best fit (smallest RMSE and largest $R^{2}$ ), likely to result from the equations being calibrated on MORECS-PET. The combination equations show the second smallest RMSE and high $R^{2}$. Hamon and McGuinness-Bordne show the largest RMSE, likely to reflect the poor fit in summer months. Oudin and Makkink have overall goodness-of-fit comparable to that of FAO56, but their poorer performance in the autumn makes them less suitable for use in hydrological models calibrated using MORECS-PET.

Of all the 12 PET equations, the combination methods (FAO56 and modified Penman-Monteith) driven by HadRM3-Q0 reproduce best the spatial and seasonal variability of MORECS PET in Great Britain. Although their associated RMSE is not always the lowest amongst all considered methods, it is consistently low, suggesting that possible biases in HadRM3-Q0 climate do not affect PET estima- tion. In the transition months of April and October, where PET is often of the same order of magnitude as precipitation, biases in PET can propagate to river discharge estimates over several seasons as recharge processes can be delayed/advanced. For those months FAO56 shows acceptable reproduction of MORECS PET. This study also showed that PET methods based on radiation and temperature can reproduce MORECS PET well for some months, but no single method consistently outperforms the others across Great Britain throughout the year.

\subsection{Future projections}

Percentage changes between mean monthly HadRM3-Q0driven PET calculated for the 1961-1990 and 2041-2070 time slices are shown in Fig. 3 for January, April, July and October and all months in Supplement.

January percentage changes are the largest but are based on small absolute values of PET. Both Priestley-Taylor versions suggest a decrease in PET in Scotland when net radiation is used directly from HadRM3-Q0 estimates, with an additional decrease in northern England for the simplified version. Changes estimated from both combined methods, Hamon, and calibrated Blaney-Criddle equations are within the ensemble of projections with Scotland showing the greatest increases.

For April, July and October nearly all the PET methods show increases in PET across nearly all of GB, but the spatial pattern of changes varies with season and method. In April Turc, Jensen-Haise and calibrated Blaney-Criddle methods 

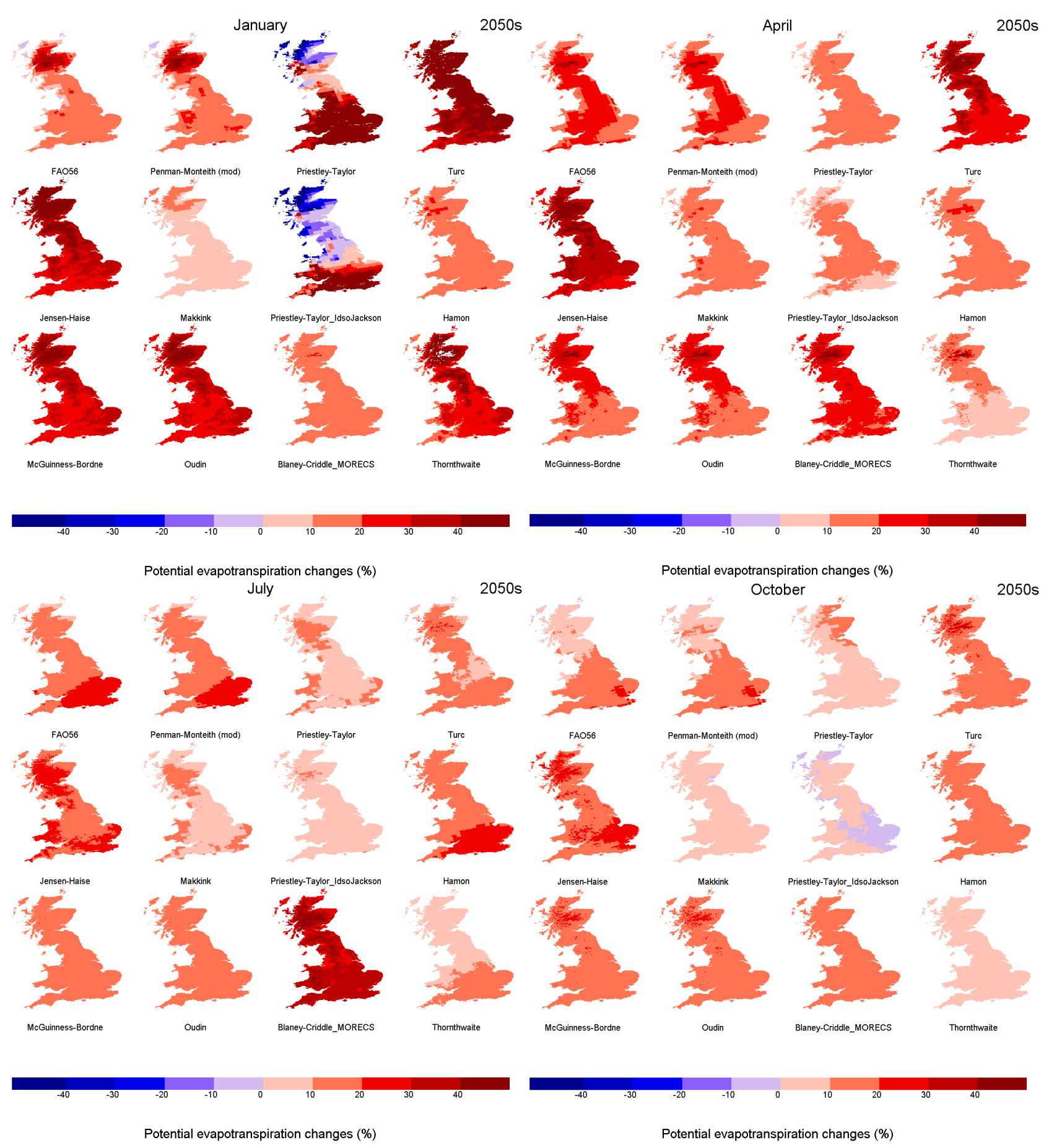

Fig. 3. PET percentage changes between averages values calculated for the 1961-1990 and 2040-2069 time slices for the 12 PET methods and four typical months. 
are associated with the largest percentage increases in PET (over $30 \%$ across most of GB for Jensen-Haise) and show a northwest-southeast gradient (largest increases in western Scotland), while in July calibrated Blaney-Criddle suggests increase in PET exceeding $30 \%$. Such increases are not reproduced by any other method and could be due to the sole use of changed temperature to estimate PET changes. In contrast Makkink, Priestley-Taylor (both versions), and Thornthwaite equations suggest the lowest changes for all three months (April, July and October), but the spatial pattern of their projected changes varies. In July both combination methods suggest largest PET increase in south and east of England (up to $30 \%$ ) while the rest of the country is associated with changes between 10 and $20 \%$, a pattern also shown by Hamon. Priestley-Taylor, Makkink, and Thornthwaite are associated with the lowest July changes, ranging from 0 to $10 \%$ for most of the country, and up to $20 \%$ in southern and eastern England for Thornthwaite and in western Scotland and western Wales for Makkink and Priestley-Taylor. In October all of the PET methods except Priestley-Taylor IdsoJackson show an increase in PET between 0 and $30 \%$ with higher percentage changes generally occurring in the southeast and in the Scottish Highlands. The combination methods show the same northwest-southeast gradient of changes as in July but with lower magnitude, well within the range of changes showed by the 12 methods. The results show a clear uncertainty introduced by the PET equations as estimates of changes can vary by more than $40 \%$ at a point depending on method used.

For all months, changes derived using the FAO56 method are within the range of changes derived from the different empirical equations, hence within PET change uncertainty. This is not the case for most temperature-driven methods which show the largest increases/decreases depending the method, month and location considered. Radiation-based methods can also be associated with large increases and decreases. The smaller magnitude changes in PET suggested by FAO56 compared to simpler methods might result from different trends in the different component of evaporation processes, which could drive large changes in PET when considered in isolation but could cancel out when they are all considered together. Despite the bias-correction procedure having been implemented only for temperature, the combination equations and the FAO56 method in particular reproduces well baseline climate and project changes within the range of other methods, suggesting that the FAO56 method is a good candidate for use in hydrological models calibrated using MORECS PET. In contrast, some temperature-driven methods can provide some very large changes, possibly because they rely too much on temperature rise and do not account for other mechanisms such as the possible increase in relative humidity, for example.

\section{Discussion and conclusions}

Kingston et al. (2009) asked whether it is better to use the more reliable estimates of potential evapotranspiration PET that can be obtained from physically based equations such as Penman-Monteith but with potentially uncertain data inputs, or to use empirical methods of estimating PET that only use the more reliable data inputs such as temperature. This study shows that, for Great Britain, the combination equations of FAO56 (Allen et al., 1998) and modified PenmanMonteith (Kay et al., 2003) used with HadRM3-Q0 climate (and consistently derived estimates of radiation) as input closely reproduce the spatial variability of MORECS mean monthly PET calculated between 1961 and 1990, suggesting that HadRM3-Q0 reproduces the climate drivers of evaporative processes with sufficient accuracy for physically based PET equations to be used.

The baseline potential evaporation used in this study (MORECS PET) was calculated from climate observations for a $40 \mathrm{~km}$ grid mesh over GB using a modification of the original Penman-Monteith equation that takes into account the land use in each square (Hough and Jones, 1997). As the equation is based on Penman-Monteith, it is perhaps not surprising that the two PET methods that most closely reproduce the spatial and temporal pattern in MORECS are the ones that are also based on the Penman-Monteith equation: FAO56 (Allen et al., 1998) and the version of Penman-Monteith modified for use with RCM data (Kay et al., 2003). This result shows that, over the control time period, the PET calculated using these combined equations is not adversely affected by any pre-existing biases in the RCM input data previously identified (e.g. Ekström et al., 2007; Kay and Davies, 2008). This also means that the bias-correction methodology implemented here, which treats temperature independently from the other climate variables, does not introduce any physical discontinuities impacting on PET estimation, at least for the 1961-1990 time slice.

Although the simpler radiation- and temperature-based equations were tested to see if they out-performed the Penman-Monteith derivatives given RCM input data rather than observed data, the results of this study show that none of these equations consistently gives PET values that are as close to the MORECS PET data as FAO56 and the modified Penman-Monteith. Previous studies have found contrasting results when comparing different PET methods. Trajkovic and Kolakovic (2009) and Xystrakis and Matzarakis (2011) found that Turc reproduced reference PET values more closely than any other radiation- or temperature-based equation in humid and arid environments respectively. However, Bormann (2011) found that Turc underestimated PET values in a study using six sites across Germany. In general, studies have found that the radiation-based methods more closely reproduce reference PET than temperature-based methods (Shaw and Riha, 2011; Trajkovic and Kolakovic, 2009; Fisher et al., 2011), although Xu and Singh (2002) 
showed that, provided locally determined parameters were used, Makkink, Priestley-Taylor, and Blaney-Criddle all reproduced PET data from Switzerland. In a comparison of PET methods across America, Federer et al. (1996) showed that Jensen-Haise overestimated summer PET, especially in hot, sunny climates, while Priestley-Taylor underestimated PET in grasslands, and the temperature-based methods Thornthwaite and Hamon showed a seasonal lag in PET values. This is likely to be because the summer peak in temperature occurs later in the year than the peak in net radiation and plant growth, and temperature correlates with net radiation rather than radiation being a main driver of PET in itself (Shaw and Riha, 2011).

When comparing changes in PET between reference 1961-1990 and future 2041-2070 time slices, results are very dependent on the PET equations used. PET percentage changes in spring and summer are generally higher for the temperature-based than for the radiation-based methods. This is in agreement with results from Shaw and Riha (2011), who found that, in New York forests, the Hamon equation predicted a $40 \%$ increase in PET by the end of the 21 st century, whereas the Priestley-Taylor equation only predicted an $11 \%$ increase over the same period. These results are likely to be because temperature is used in the temperature-based equations as a proxy for net radiation. Shaw and Riha (2011) showed that the GFDL CM GCM with the A2 emission scenario predicted an increase in temperature of $33 \%$ in New York state by the end of the 21 st century, but over the same time period net radiation was only predicted to increase by $2.5 \%$. In our study, combined methods are usually associated with changes within the envelope of changes given by all other methods.

The purpose of this study was to identify which PET equation should be used to best construct PET from HadRM3Q0 climate simulations for use in hydrological models. Because, in the UK, MORECS-PET is generally used as reference PET to calibrate conceptual hydrological models, this study investigated which empirical PET formulation reproduces best MORECS-PET across Great Britain and for different seasons, and if their associated future changes were within the uncertainty band from all tested PET formulations. The combined (physically based) method FAO56 was found to provide a good reproduction of the spatial variability of MORECS-PET across Britain at any time of the year, and to be associated with future projections within the range suggested by other PET methods and is hence recommended. This result is likely to be due to the similarity in the equations used to estimate PET from HadRM3-Q0 with those used in MORECS (combined equations for both), and the conclusions would likely change if a different equation were used to define reference PET. While only HadRM3-Q0 temperature time series was bias-corrected, potentially generating some physical inconsistencies with non-bias-corrected climate variables (such as radiation or relative humidity), the results suggest that this simplification is acceptable as FAO56-
PET estimations are close to MORECS-PET for the reference period. This is a source of uncertainty associated with future PET estimates.

Another source of uncertainty highlighted here is that associated with the method used to estimate PET. In the transition months of April and October, when PET monthly totals are often of similar size to precipitation totals in some regions of England, estimates of future changes can vary by a factor of 1 to 3 , and for some regions change direction depending on the method. Note finally that only a single regional climate model simulation was used here (HadRM3-Q0). Because of the known variation in projected climate from different climate model structures and variants, it is not guaranteed that, for other G/RCM, the biases in the climate simulation would lead to realistic reproduction of MORECS-PET and that a different PET formulation might be preferable.

Uncertainty in climate model outputs, including their simulation of the rate of evaporation, is well recognised in the literature (e.g. Boé and Terray, 2008; Kingston et al., 2009); the consequences for the estimation of PET and its changes and the role of this uncertainty on estimates of changes in river flow statistics have also recently been recognised (e.g. Kay and Davies, 2008). However, PET uncertainty has rarely been fully compared to other sources of uncertainty, such as GCM, downscaling or hydrological model uncertainty in climate change impact studies (e.g. Prudhomme and Davies, 2009; Kay et al., 2009; Wilby and Harris, 2006; Blenkinsop and Fowler, 2007; Jung et al., 2012; Boé et al., 2009). This study suggests that uncertainty in estimated PET exists and needs to be quantified, and that PET is a challenge facing the assessment of climate change impact on hydrology mostly ignored up to now.

\section{Supplementary material related to this article is available online at: http://www.hydrol-earth-syst-sci.net/ 17/1365/2013/hess-17-1365-2013-supplement.pdf.}

Acknowledgements. This study was undertaken under the partnership project "Future Flows and Groundwater Levels, SC090016" jointly funded by the Environment Agency of England and Wales, the UK Department for Environment, Food and Rural Affairs, the UK Water Industry Research, the Natural Environment Research Centre (CEH and BGS) and Wallingford HydroSolutions. They are all gratefully acknowledged. The authors are very grateful to Helen Davies, Eleanore Boelee and George Goodsell for help with the data, to Sue Crooks for advise on the role of PET in hydrological modelling and to Doug Clark for scientific review. The views expressed are those of the authors and not of the funding organisations. HadRM3-Q0 time series were obtained from the British Atmospheric Data Centre (www.badc.nerc.ac.uk). MORECS PET was obtained from the National River Flow Archive (http://www.ceh.ac.uk/data/nrfa/). We also would like to thank helpful comments from M. Ekstrom, C. Beales and J.-P. Vidal which contributed to improve the manuscript.

Edited by: B. Schaefli 


\section{References}

Allen, R. G., Pereira, L. S., Raes, D., and Smith, M.: FAO irrigation and drainage paper 56 - Crop evapotranspiration - Guidelines for computing crop water requirements, Food and Agriculture Organisation of the United Nations, Rome, 300, 1998.

Bell, V. A., Gedney, N., Kay, A. L., Smith, R. N. B., Jones, R. G., and Moore, R. J.: Estimating Potential Evaporation from Vegetated Surfaces for Water Management Impact Assessments Using Climate Model Output, J. Hydrometeorol., 12, 1127-1136, doi:10.1175/2011jhm1379.1, 2011.

Blaney, H. F. and Criddle, W. D.: Determining water requirements in irrigated areas from climatological and irrigation data, Washington, USA, 48, 1950.

Blenkinsop, S. and Fowler, H. J.: Changes in European drought characteristics projected by the PRUDENCE regional climate models, Int. J. Climatol., 27, 1595-1610, 2007.

Boé, J. and Terray, L.: Uncertainties in summer evapotranspiration changes over Europe and implications for regional climate change, Geophys. Res. Lett., 35, L05702, doi:10.1029/2007GL032417, 2008.

Boé, J., Terray, L., Martin, E., and Habets, F.: Projected changes in components of the hydrological cycle in French river basins during the 21st century, Water Resour. Res., 45, W08426, doi:10.1029/2008wr007437, 2009.

Bormann, H.: Sensitivity analysis of 18 different potential evapotranspiration models to observed climatic change at German climate stations, Clim. Change, 104, 729-753, doi:10.1007/s10584010-9869-7, 2011.

Chin, D. A.: Thermodynamic consistency of potential evapotranspiration estimates in Florida, Hydrol. Process., 25, 288-301, 2011.

Christensen, J., Kjellstrom, E., Giorgi, F., Lenderink, G., and Rummukainen, M.: Weight assignment in regional climate models, Clim. Res., 44, 179-194, doi:10.3354/cr00916, 2010.

Christierson, B. V., Vidal, J.-P., and Wade, S. D.: Using UKCP09 probabilistic climate information for UK water resource planning, J. Hydrol., 424-425, 48-67, doi:10.1016/j.jhydrol.2011.12.020, 2012.

Crooks, S. M. and Naden, P. S.: CLASSIC: a semi-distributed rainfall-runoff modelling system, Hydrol. Earth Syst. Sci., 11, 516-531, doi:10.5194/hess-11-516-2007, 2007.

Donohue, R. J., McVicar, T. R., and Roderick, M. L.: Assessing the ability of potential evaporation formulations to capture the dynamics in evaporative demand within a changing climate, J. Hydrol., 386, 186-197, 2010.

Ekström, M., Jones, P. D., Fowler, H. J., Lenderink, G., Buishand, T. A., and Conway, D.: Regional climate model data used within the SWURVE project - 1: projected changes in seasonal patterns and estimation of PET, Hydrol. Earth Syst. Sci., 11, 1069-1083, doi:10.5194/hess-11-1069-2007, 2007.

Federer, C. A., Vorosmarty, C. J., and Fekete, B.: Intercomparison of methods for calculating potential evaporation in regional and global water balance models, Water Resour. Res., 32, 23152321, 1996.

Fisher, J. B., Whittaker, R. J., and Malhi, Y.: ET come home: potential evapotranspiration in geographical ecology, Global Ecol. Biogeogr., 20, 1-18, 2011.

Hamon, W. R.: Estimating potential evapotranspiration, J. Hydr. Div.-ASCE, 87, 107-120, 1961.
Hay, L. E., Clark, M. P., Wilby, R. L., Gutowski, W. J., Leavesley, G. H., Pan, Z., Arritt, R. W., and Takle, E. S.: Use of regional climate model output for hydrologic simulations, J. Hydrometeorol., 3, 571-590, doi:10.1175/15257541(2002)003<0571:UORCMO>2.0.CO;2, 2002.

Hough, M. N. and Jones, R. J. A.: The United Kingdom Meteorological Office rainfall and evaporation calculation system: MORECS version 2.0-an overview, Hydrol. Earth Syst. Sci., 1, 227-239, doi:10.5194/hess-1-227-1997, 1997.

IPCC: Special report on emissions scenarios (SRES): A special report of Working Group III of the Intergovernmental Panel on Climate Change, Cambridge University Press, Cambridge, 599 pp., 2000.

Jacobs, A. F. G., Heusinkveld, B. G., and Holtslag, A. A. M.: Eighty years of meteorological observations at Wageningen, the Netherlands: precipitation and evapotranspiration, Int. J. Climatol., 30, 1315-1321, doi:10.1002/joc.1957, 2009.

Jensen, M. E. and Haise, H. R.: Estimating evapotranspiration from solar radiation, J. Irr. Drain. Div.-ASCE, 89, 15-41, 1963.

Jensen, M. E., Burman, R. D., and Allen, R. G. (Eds.): Evapotranspiration and irrigation water requirements, ASCE Manuals and Reports on Engineering Practice No. 70, American Society of Civil Engineers: New York. 332pp., 1990.

Jung, I.-W., Moradkhani, H., and Chang, H.: Uncertainty assessment of climate change impacts for hydrologically distinct river basins, J. Hydrol., 466-467, 73-87, doi:10.1016/j.jhydrol.2012.08.002, 2012.

Kay, A. L. and Davies, H. N.: Calculating potential evaporation from climate model data: a source of uncertainty for hydrological climate change impacts, J. Hydrol., 358, 221-239, 2008.

Kay, A. L., Bell, V. A., Moore, R. J., and Jones, R. G.: Estimation of UK flood frequencies using RCM rainfall: an initial investigation, CEH, Wallingford, 40, 2003.

Kay, A. L., Jones, D. A., Crooks, S. M., Kjeldsen, T. R., and Fung, C. F.: An investigation of site-similarity approaches to generalisation of a rainfall-runoff model, Hydrol. Earth Syst. Sci., 11, 500-515, doi:10.5194/hess-11-500-2007, 2007.

Kay, A. L., Davies, H. N., Bell, V. A., and Jones, R. G.: Comparison of uncertainty sources for climate change impacts: flood frequency in England, Clim. Change, 92, 41-63, doi:10.1007/s10584-008-9471-4, 2009.

Kingston, D., Todd, M., Taylor, R. G., Thompson, J. R., and Arnell, N. W.: Uncertainty in the estimation of potential evapotranspiration under climate change, Geophys. Res. Lett., 36, L20403, doi:10.1029/2009GL040267, 2009.

Leander, R. and Buishand, T. A.: Resampling of regional climate model output for the simulation of extreme river flows, J. Hydrol., 332, 487-496, 2007.

Lenderink, G., Buishand, A., and van Deursen, W.: Estimates of future discharges of the river Rhine using two scenario methodologies: direct versus delta approach, Hydrol. Earth Syst. Sci., 11, 1145-1159, doi:10.5194/hess-11-1145-2007, 2007.

Monteith, J. L.: Evaporation and environment, Symposia of the society for experimental biology, 1965.

Murphy, J. M., Sexton, D. M. H., Jenkins, G. J., Booth, B. B. B., Brown, C. C., Clark, R. T., Collins, M., Harris, G. R., Kendon, E. J., Betts, R. A., Brown, S. J., Humphrey, K. A., McCarthy, M. P., McDonald, R. E., Stephens, A., Wallace, C., Warren, R., Wilby, R., and Wood, R. A.: UK Climate Projections Science 
Report: Climate Change Projections, Met Office Hadley Centre, Exeter, UK, 190, 2009.

Oudin, L., Hervieu, F., Michel, C., Perrin, C., Andreassian, V., Anctil, F., and Loumagne, C.: Which potential evapotranspiration input for a lumped rainfall-runoff model?: Part 2-Towards a simple and efficient potential evapotranspiration model for rainfallrunoff modelling, J. Hydrol., 303, 290-306, 2005.

Penman, H. L.: Natural evaporation from open water, bare soil and grass, Proc. R. Soc. Lond., A, 120-145, 1948.

Perry, M., Hollis, D., and Elms, M.: The generation of daily gridded datasets of temperature and rainfall for the UK, National Climate Information Centre, Met Office, Exeter, 7, 2009.

Piani, C., Weedon, G. P., Best, M., Gomes, S. M., Viterbo, P., Hagemann, S., and Haerter, J. O.: Statistical bias correction of global simulated daily precipitation and temperature for the application of hydrological models, J. Hydrol., 395, 199-215, 2010.

Priestley, C. H. B. and Taylor, R. J.: On the assessment of surface heat flux and evaporation using large-scale parameters, Mon. Weather Rev., 100, 81-92, 1972.

Prudhomme, C. and Davies, H.: Assessing uncertainties in climate change impact analyses on the river flow regimes in the UK. Part 2: future climate, Clim. Change, 93, 197-222, doi:10.1007/s10584-008-9461-6, 2009.

Shaw, S. B. and Riha, S. J.: Assessing temperature-based PET equations under a changing climate in temperate, deciduous forests, Hydrol. Process., 25, 1466-1478, doi:10.1002/hyp.7913, 2011.

Shuttleworth, W. J.: Evaporation, in: Handbook of hydrology, edited by: Maidment, D. R., McGraw-Hill, Inc, 4.1-4.53, 1993.

Terink, W., Hurkmans, R. T. W. L., Torfs, P. J. J. F., and Uijlenhoet, R.: Evaluation of a bias correction method applied to downscaled precipitation and temperature reanalysis data for the Rhine basin, Hydrol. Earth Syst. Sci., 14, 687-703, doi:10.5194/hess-14-6872010, 2010.
Thornthwaite, C. W.: An approach toward a rational classification of climate, Geogr. Rev., 38, 55-94, 1948.

Trajkovic, S. and Kolakovic, S.: Evaluation of Reference Evapotranspiration Equations Under Humid Conditions, Water Resour. Manage., 23, 3057-3067, doi:10.1007/s11269-009-9423-4, 2009.

Turc, L.: Evaluation des besoins en eau d'irrigation, evapotranspiration potentielle, Ann. Agron., 12, 13-49, 1961.

Wilby, R. L. and Harris, I.: A framework for assessing uncertainties in climate change impacts: Low-flow scenarios for the River Thames, UK, Water Resour. Res., 42, W02419, doi:10.1029/2005wr004065, 2006.

$\mathrm{Xu}, \mathrm{C}$. Y. and Singh, V. P.: Dependence of evaporation on meteorological variables at different time-scales and intercomparison of estimation methods, Hydrol. Process., 12, 429-442, 1998.

$\mathrm{Xu}$, C. Y. and Singh, V. P.: Cross Comparison of Empirical Equations for Calculating Potential Evapotranspiration with Data from Switzerland, Water Resour. Manage., 16, 197-219, doi:10.1023/a:1020282515975, 2002.

Xystrakis, F. and Matzarakis, A.: Evaluation of 13 empirical reference potential evapotranspiration equations on the island of Crete in southern Greece, J. Irr. Drain. Eng., 137, 211-222, 2011.

Young, A. R.: Stream flow simulation within UK ungauged catchments using a daily rainfall-runoff model, J. Hydrol., 320, 155172, 2006. 